\title{
Necrológica
}

\section{LA MUERTE DE AUGUSTO D'HALMAR}

En su patria, Chile, ha muerto el novelista Augusto D'Halmar. Se despedía así al escritor recientemente desaparecido: "Chile ha colocado un solemne crespón sobre la estrella solitaria de nuestra bandera, por la partida de este maestro de la literatura chilena que aúna la belleza, la fraternidad y la libertad por encima de toda consideración. Sabemos que aunque su recuerdo flotará siempre junto a nosotros, un vacío quedará, porque nunca como hoy se necesita más la acción y la palabra de hombres como Augusto D'Halmar, que ya no tendremos, porque, como Nervo lo cantara, se ha ido a "cumplir la cita sobre la arena infinita de una playa sideral'. Y agregaba: "En él se resumen cincuenta años de agitada vida literaria. Amigo de los más grandes artistas del mundo era el nexo que nos ataba a un pasado intelectual que recordábamos con delectación y ternura. Contó con el afecto de Antonio Machado y de Federico García Lorca, quien lo llamaba cariñosamente "su confesor laico". Entrañable amigo de Maeterlinck; de Oscar Lubic Milosz, el delicado poeta lituano; de Pierre Loti, el amador del Mar y del Oriente, como él; de Rodin, el escultor incomparable, y tantos otros que ya han cruzado mansa y silenciosamente la laguna Estigia. Faltaba él solamente, nuestro D'Halmar, como le decíamos, y muchas veces al pensarlo no nos resignábamos a tener que perderlo algún día." Sombra era ya Augusto D'Halmar. En su juventud "siguió una evolución típica de muchos de los que huyen de la realidad-dice Torres Rioseco en La novela hispanoamericana. Primero se ensayó en el más crudo realismo teñido de filosofía tolstoiana, intentando poner en práctica sus principios en una colonia literaria vege- 
tariana; luego, designado Cónsul de Chile en Calcuta, se hundió en el exotismo oriental con sus libros de croquis de viajes, misteriosos y evocadores de ambiente, como Nirvana, 1918, y La sombra del humo en el espejo, 1924. Por último, en Pasión y muerte del cura Deusto, 1924, compuso una novela exótica cuya acción se desarrolla en Sevilla: pinta la hermosa ciudad andaluza, sus tipos estrambóticos, las iglesias, los cafés, las procesiones religiosas, con intensa alegría de vivir, con apasionado cariño por la ciudad en sí y en impecable forma literaria."

Fue de los escritores que en las dos primeras decenas de este siglo buscaron horizontes más amplios que los que pudiera proporcionarle nuestra América. Huyó de su tierra para viajar por el mundo. El Oriente le atrajo especialmente. Se había ya europeizado completamente. Para ello respondía, en buena parte, a sus orígenes nórdicos. Su nombre verdadero fue Augusto Thomson. Le interesan en sus obras los personajes atormentados, inquietos, presas de obsesiones irrefrenables. Penetra sutilmente en el alma de sus personajes, los analiza, los diseca "pero infunde en sus creaciones una inquieta sensibilidad de sudamericano", dice otro de sus críticos. El ambiente de su tierra, decimos nosotros, había ejercido inevitablemente su influjo en él y en su obra.

Nació en 1880; en 1916 formó parte del grupo de "Los diez", que tuvo importante influencia en la literatura chilena. Además de las obras citadas, produjo Juana Lucero o los vicios de Chile, de entronque naturalista; Gatita, de ambiente peruano; La lámpara en el molino; Capitanes sin barco y Amor cara a cara. Su país pierde a un artista de espíritu inquieto y batallador; América, a uno de sus artistas que, desde fuera, supieron hacerla sentir en los más apartados rincones de la tierra.

J. J. R. 